\title{
GRONINGEN RADIOCARBON DATES IX
}

\author{
J. C. VOGEL \\ University of Groningen, Netherlands*
}

INTRODUCTION

This list contains mainly radiocarbon dates for Africa. Some results for samples from the ocean floor and from islands in the Atlantic and Indian oceans, as well as a few series of geophysical samples have also been included. The results are grouped into three categories: geologic, archaeologic, and geophysical, and arranged according to the country of provenance, passing roughly from $\mathrm{N}$ to $\mathrm{S}$. Descriptions and comments are based on information supplied by the collectors and submitters and on the publications cited. In several cases insufficient information was available, but since it is improbable that it will be forthcoming, the dates have been included.

Unless otherwise stated, organic material (wood, peat, charcoal, etc.) was pretreated in the usual manner, with dilute acid, alkali, and acid, re-spectively. The outer layers of shell and other carbonate samples were etched off with dilute acid and the inner carbonate dated. Results are expressed in terms of the conventional $\mathrm{C}^{14}$ scale as defined in the Editorial Statement of RadIOCARBON (w.r.t. NBS oxalic acid standard; $\mathrm{t}_{1 / 2}=5568$ years).

$\mathrm{C}^{13} / \mathrm{C}^{12}$ ratios of most samples were measured under the supervision of W. G. Mook. Where $\delta \mathrm{C}^{13}$ values are given for organic material (all relative to the PDB standard), results are corrected for deviations from the "normal" value of $\delta \mathrm{C}^{13}=-25.0 \%$. In the case of shell and limestone, no such corrections are applied since experience shows that this is unnecessary.

Due to secular variations in the initial radiocarbon concentration during the last few hundred years (de Vries, 1958), conventional radiocarbon dates can be in error by as much as 160 years. Based on some 40 tree-ring samples from A.D. 1400 onwards (Lerman, Mook, and Vogel, 1970) a calibration curve for the $S$ hemisphere has been constructed by which the most probable historic date for radiocarbon measurements in this time range can be deduced (Fig. 1). This curve has been used for interpreting the Iron age dates for S Africa given in Section II C.

Thanks are due to all who have assisted in the measurements, especially H. J. Streurman and G. H. Pijpen $\left(\mathrm{C}^{14}\right)$, and C. Sijbolts $\left(\mathrm{C}^{13}\right)$ who have performed the analyses during the past few years. Since January 1969, W. G. Mook has assumed responsibility for the laboratory (GrN5680 onward). A few results measured since then are also included in this list.

* Physics Laboratory, Westersingel 34, Groningen. Present address: National Physics Research Laboratory, P.O. Box 395, Pretoria, South Africa. 


\section{SAMPLE DESCRIPTIONS}

I. GEOLOGY AND PALYNOLOGY

\section{A. North and East Africa}

\section{Morocco series}

Samples coll. by G. Choubert, Rabat, from various sites near Moroccan coast to date emerged beaches. The three youngest marine phases in the region are, with increasing age: Rharbian (sea level slightly higher than present), $+2 \mathrm{~m}$ Flandrian beach, and Soltanian, during which a red soil was widely deposited. Unfortunately, it was not possible to obtain data on provenance and significance of samples from submitter or collector. Subm. by G. C. Maarleveld, Kerkweg 56, Ede, Netherlands.

\section{GrN-2198. Dar el Assairia}

\section{A.D. 1670}

$280 \pm 60$

Charcoal, $2.5 \mathrm{~m}$ below gray deposit in black soil formed during the Rharbian at Dar el Assairia (34 $30^{\prime} \mathrm{N}$ Lat, $6^{\circ} \mathrm{W}$ Long) on Beth R., Rharb. Comment: pretreated with acid.

\section{GrN-5571. Sidi Kacem 2}

$$
\begin{array}{r}
1900 \pm 30 \\
\text { A.D. } 50
\end{array}
$$

$$
\delta C^{13}=-8.0 \%
$$

Shells at $1.5 \mathrm{~m}$ depth at M'Saada near Sidi Kacem $\left(34^{\circ} 15^{\prime} \mathrm{N}\right.$ Lat, $5^{\circ} 49^{\prime} \mathrm{W}$ Long) deposited during Rharbian phase.

\section{GrN-5572. Sidi Kacem 1}

$$
\begin{array}{r}
1950 \pm \mathbf{3 0} \\
\text { A.D. } 1 \\
\delta C^{13}=-7.0 \% 0
\end{array}
$$

Shells from $2 \mathrm{~m}$ depth at Dar Hamancha on Ouerrha R. near Sidi Kacem deposited during Rharbian phase.

\section{GrN-5188. Canal du Rharb}

$5030 \pm 35$ 3080 в.C.

Shells from ca $4 \mathrm{~m}$ depth on $\mathrm{Rh}$ (35 $\mathrm{N}$ Lat, $6^{\circ} \mathrm{W}$ Long) supposed to date Rharbian.

\section{GrN-3149. Temara 2}

$1300 \pm 60$

Shells from kitchen midden at Temara near Rabat $\left(34^{\circ} 02^{\prime} \mathrm{N}\right.$ Lat, $6^{\circ} 51^{\prime}$ W Long) thought to date Rharbian.

GrN-2805. Temara 1

$\mathbf{5 7 2 0} \pm \mathbf{5 0}$

3770 B.c.

Shells from $+2 \mathrm{~m}$ on Flandrian terrace at Temara. Comment: should provide good approx. date for Flandrian emerged beach.

GrN-3153. Ras el Ma

$5330 \pm 75$

3380 B.c.

Shells from ca. $2 \mathrm{~m}$ depth at Ras el Ma near Fès $\left(34^{\circ} 05^{\prime} \mathrm{N}\right.$ Lat, $5^{\circ} 00^{\prime} \mathrm{W}$ Long) dating from Flandrian phase. 
GrN-3156. Côte de Miramar

Shell in red soil formed between high sea level phases of Flandrian and Tyrrhenian III (Ouljian) from Miramar near Rabat (34 $02^{\prime} \mathrm{N}$ Lat, $06^{\circ} 51^{\prime} \mathrm{W}$ Long), intended to date soil formation during Soltanian phase.

GrN-3165. Ain Maarouf

$32,000 \pm 600$ 30,050 B.C.

Shells from $0.3 \mathrm{~m}$ depth in fossil soil of Soltanian age at Ain Maarouf near el Hajeb $\left(33^{\circ} 40^{\prime} \mathrm{N}\right.$ Lat, $05^{\circ} 20^{\prime} \mathrm{W}$ Long).

GrN-5570. Oued Charef

$$
\begin{gathered}
11,360 \pm 75 \\
\text { 9410 B.c. } \\
\delta C^{1 s}=-5.9 \% 0
\end{gathered}
$$

Shells from shell bed on road Berguent-Mekame $\left(34^{\circ} 03^{\prime} \mathrm{N}\right.$ Lat, $02^{\circ} 02^{\prime} \mathrm{W}$ Long) thought to be of Rharbian or Soltanian age.

General Comment: 1st 5 dates suggest Rharbian high water (or wet?) phase to date between Roman and Middle ages. Next 2 samples date $+2 \mathrm{~m}$ Flandrian high sea level to 4 th millennium B.c., while last 3 samples suggest red soil perhaps of Denekamp interstadial age. All shell samples treated with dil. acid, shell carbonate dated.

GrN-5875. Chiccio, Ethiopia, No. 4012

$$
\begin{aligned}
& \quad \mathbf{7 2 0} \pm \mathbf{7 5} \\
& \text { A.D. } 1230 \\
& \delta C^{1 s}=-24.9 \%
\end{aligned}
$$

Small peat sample from 100 to $105 \mathrm{~cm}$ depth in boring in Chiccio Valley ( $7^{\circ} 44^{\prime} \mathrm{N}$ Lat, $36^{\circ} 26^{\prime}$ E Long) Kaffa Prov., Ethiopia. Coll. and subm. 1967 by E. M. van Zinderen Bakker, Univ. of Orange Free State, Bloemfontein.

Comment: date for bottom of $9 \mathrm{~m}$ core is I-2619: $33,500 \begin{aligned} & +4000 \\ & -3100\end{aligned}$ B.P.

GrN-5876. Kilotes, Ethiopia, No. 3824-6, 3880

$825 \pm 90$

A.D. 1125

$\delta C^{13}=-15.2 \%$

Small sample of lake sediment from boring at 180 to $200 \mathrm{~cm}$ depth in Lake Kilotes $\left(8^{\circ} 48^{\prime} \mathrm{N}\right.$ Lat, $39^{\circ} 05^{\prime} \mathrm{E}$ Long) Shoa Prov., Ethiopia. Coll. and subm. 1967 by E. M. van Zinderen Bakker. Comment: core extends to $1450 \mathrm{~cm}$.

\section{Cherangani Hills series, Kenya}

Kaisungor swamp at ca. $2900 \mathrm{~m}$ alt in Cherangani Hills in NW Kenya ( $1^{\circ} \mathrm{N}$ Lat, $35^{\circ} 28^{\prime} \mathrm{E}$ Long) is filled with sediment containing organic matter and pollen. In 1960 Core A was taken by E. M. van Zinderen Bakker in center of swamp which lies at upper end of a valley within montane forest (van Zinderen Bakker, 1962, 1964). Pollen diagram showed core to cover Late and Post-Glacial times. In 1961, Core $\mathrm{B}$ was taken to obtain more and possibly older material (Coetzee and 
Vogel, 1967; Coetzee, 1967). Coll. and subm. 1961 by E. M. van Zinderen Bakker.

\section{GrN-3048. Kaisungor A, No. 1686}

GrN-2423. Kaisungor A, acid only

$$
12,690 \pm 100
$$$$
10,740 \text { B.c. }
$$

$11,810 \pm 140$ 9860 B.C.

Organic sediment from 285 to $300 \mathrm{~cm}$ depth in Core A in Kaisungor swamp. Pollen diagram shows high percentages of grass and Alchemilla (ericaceous belt) representing cold period which is followed by warmer climate at 2.75 to $2.50 \mathrm{~m}$ depth equated with Aller $\phi \mathrm{d}$ Interstadial in Europe. Comment: GrN-3048 fully treated with acid and alkali; GrN2423 , pretreated with acid only, gives too young date. GrN-3048 shows that climatic changes during Late and Post-Glacial were contemporaneous with those in Europe.

GrN-4061. Kaisungor B, 115, No. 2259

A.D. 1185

Plant remains from 112 to $117 \mathrm{~cm}$ depth in Core B.

GrN-4071. Kaisungor B, 230, No. 2261

$1520 \pm 135$

Plant remains from 228 to $234 \mathrm{~cm}$ depth in Core $\mathrm{B}$.

GrN-4063. Kaisungor B, 250, No. 2262

A.D. 430

Plant remains from 247 to $253 \mathrm{~cm}$ depth in Core B.

GrN-4072. Kaisungor B, 272, No. 2263

$1900 \pm 70$ A.D. 50

Plant remains from 270 to $275 \mathrm{~cm}$ depth in Core B.

GrN-4062. Kaisungor B, 370, No. 2264

$2150 \pm 220$

200 B.C.

Plant remains from 363 to $377 \mathrm{~cm}$ depth in Core B.

$17,000 \pm 300$ 15,050 в.C.

GrN-4089. Kaisungor B, 462, No. 2265

$27,750 \pm 600$

Plant remains from 456 to $468 \mathrm{~cm}$ depth in Core B.

General Comment: all samples except GrN-2423 pretreated with acid and alkali. Core B was expected to be similar to Core A, but dates show that it must have struck a gully filled with recent sediment down to at least $275 \mathrm{~cm}$. As is indicated by alpine grassland pollen spectra, material of glacial age is preserved between 328 and $470 \mathrm{~cm}$. At bottom of diagram, spectra show site was in lowest part of ericaceous belt, indicating a climatic amelioration at or before 27,750 yr B.P. Cf. Mt. Kenya series below.

\section{Mount Kenya series, Kenya}

Bottom deposits from 2 lakes on Mt. Kenya, Kenya, Lake Rutundu $\left(0^{\circ} 03^{\prime} \mathrm{N}\right.$ Lat, $37^{\circ} 28^{\prime} \mathrm{E}$ Long) at $3100 \mathrm{~m}$ alt and Sacred Lake $\left(0^{\circ} 03^{\prime}\right.$ 
N Lat, $37^{\circ} 32^{\prime}$ E Long) at $2440 \mathrm{~m}$ alt, both within the montane forest belt (tree line $3350 \mathrm{~m}$ ). Borings made to study climatic change by means of pollen analysis (Coetzee, 1967). Coll. and subm. by J. A. Coetzee and E. M. van Zinderen Bakker.

GrN-3511. Rutundu 1, No. 1754

$6135 \pm 85$ 4185 в.c.

Lake deposit at 410 to $440 \mathrm{~cm}$ below bottom in Lake Rutundu. Subm. 1961. Comment: pretreated with acid and alkali.

GrN-3526. Rutundu 2, No. 1747

$7330 \pm 90$ 5880 B.C.

Lake deposit at 460 to $490 \mathrm{~cm}$ below bottom from same core as Rutundu 1. Comment: pretreated with acid and alkali. Pollen spectrum at this depth shows favorable climate.

GrN-3615. Sacred Lake 1, No. 2268

$12,960 \pm 120$

Brown lake sediment at 207 to $225 \mathrm{~cm}$ below bottom from Core 1 in Sacred Lake. Subm. 1962. Comment: pretreated with acid and alkali. Pollen not analyzed.

GrN-3614. Sacred Lake 2, No. 2270

$15,400 \pm 180$

13,450 B.C.

Lake mud at 660 to $670 \mathrm{~cm}$ below bottom from Core 2 in Sacred Lake. Subm. 1962. Comment: pretreated with acid and alkali. Pollen diagram of this core by Coetzee (1964) shows site, which is at present surrounded by humid montane forest, to have lain in ericaceous belt at this time.

GrN-4195. Sacred Lake 3, No. 2647

$3285 \pm 60$ 1335 B.c.

Lake mud at 320 to $330 \mathrm{~cm}$ below bottom from Core 3 in Sacred Lake. Coll. and subm. 1963. Comment: pretreated with acid and cold alkali.

GrN-4193. Sacred Lake 4, No. 2645

$10,560 \pm 65$

8610 B.C.

Lake mud at 530 to $540 \mathrm{~cm}$ below bottom from Core 3. Comment: pretreated with acid and cold alkali.

GrN-4194. Sacred Lake 5, No. 2646

$33,350 \pm 1000$ 31,400 в.c.

Lake mud at 1185 to $1195 \mathrm{~cm}$ below bottom from Core 3. Comment: pretreated with acid and cold alkali.

General Comment: between samples Sacred Lake 3 and 5, age increases linearly with depth. Pollen diagram by Miss Coetzee shows site in ericaceous belt at $1190 \mathrm{~cm}$, with climatic improvement between 1150 and $1020 \mathrm{~cm}$ or 31,600 в.P. and ca. 27,000 в.P. by interpolation (Coetzee and Vogel, 1967), which corresponds in age with Denekamp (Paudorf) Interstadial in the Netherlands (van der Hammen et al., 1967; Vogel and Zagwijn, 1967), and with evidence from Cherangani Hills series, above. 
Pollen spectrum of Core 2 also shows contemporaneity of climatic variations with Europe in Late and Post-Glacial times (Coetzee, 1964).

\section{Naivasha series, Kenya}

Bottom deposits from Lake Naivasha, Rift Valley, Kenya $\left(0^{\circ} 45^{\prime}\right.$ S Lat, $36^{\circ} 22^{\prime}$ E Long), containing pollen. Coll. and subm. 1961 by E. M. van Zinderen Bakker.

GrN-3551. Naivasha 1, No. 1457

$2730 \pm 85$

780 B.C.

Clay from 545 to $560 \mathrm{~cm}$ below bottom of crater lake on $\mathrm{E}$ side of Lake Naivasha. Comment: pretreated with acid only. Gives date of last drying of lake which thus occurred on Sub-boreal-Sub-atlantic border.

GrN-3517. Naivasha 2, No. 1600

$680 \pm 55$

Clay and organic matter from 130 to $145 \mathrm{~cm}$ below bottom in main lake. Comment: pretreated with acid and alkali. Much younger than expected.

General Comment: pollen analysis discontinued as J. L. Richardson studied $30 \mathrm{~m}$ core from same site.

\section{GrN-3515. Lake Narasha, Kenya, No. 1729}

A.D. 1040

$910 \pm 45$

Lake deposit from $300 \mathrm{~cm}$ below bottom in Lake Narasha $\left(0^{\circ} 05^{\prime}\right.$ $\mathrm{N}$ Lat, $35^{\circ} 33^{\prime} \mathrm{E}$ Long) $2700 \mathrm{~m}$ alt, near upper limit of montane forest, E of Timboroa, Kenya. Coll. and subm. 1961 by E. M. van Zinderen Bakker. Comment: pretreated with acid and alkali. Indicates rather rapid deposition. Pollen diagram shows no appreciable difference from present-day surrounding vegetation.

\section{GrN-3510. Yatta Camp, Kenya, No. 1820}

$380 \pm 60$

Subfossil stem or root (Hydnora rhizomes) from pit, 60 to $74 \mathrm{~cm}$ below surface overlain by black clay and fine sandy loam, $1.8 \mathrm{~km} \mathrm{~S}$ of B2 Yatta Camp, Kitui Yatta area ( $1^{\circ} 09^{\prime} \mathrm{N}$ Lat, $37^{\circ} 43^{\prime} \mathrm{E}$ Long), at $1170 \mathrm{~m}$ alt. Coll. by C. G. Trapnell and subm. 1961 by Trapnell and R. M. Scott, E African Agri. and Forestry Org. and E. M. van Zinderen Bakker. Comment: pretreated with acid and alkali. Intended to date clay deposit below present soil.

\section{Kilimanjaro series, Tanzania}

Deposits in a crater lake on Kilimanjaro $\left(3^{\circ} 00^{\prime} \mathrm{S}\right.$ Lat, $27^{\circ} 23^{\prime} \mathrm{E}$ Long), Tanzania. Cored for pollen analysis 1963 (Coetzee, 1967) and subm. 1964 by E. M. van Zinderen Bakker.

\section{GrN-4370. Kilimanjaro 1, No. 2618}

$$
1530 \pm 50
$$

\section{A.D. 420}

$\delta C^{13}=-23.9 \%$

Lake mud and plant remains at 145 to $160 \mathrm{~cm}$ depth. Comment: pretreated with acid. 
GrN-4369. Kilimanjaro 2, No. 2615

$$
\begin{array}{r}
4620 \pm 50 \\
2670 \text { B.c. } \\
\delta C^{13}=-22.0 \% \text { o }
\end{array}
$$

Lake mud at 235 to $250 \mathrm{~cm}$ depth. Comment: pretreated with acid. Pumice at 230 to $242 \mathrm{~cm}$ shows nearby eruption at this date.

General Comment (J.A.C.): pollen spectrum at $250 \mathrm{~cm}$ level indicates warm period comparable with Sub-boreal climatic optimum. Spectrum at $180 \mathrm{~cm}$ suggests cooler conditions.

\section{B. Southern Africa}

\section{Oranjemund series, South West Africa}

Shells from midway down in $3 \mathrm{~m}$ deep marine gravel, filling gully and constituting lowest $(+2 \mathrm{~m})$ emerged terrace (A) ca. $56 \mathrm{~km} \mathrm{~N}$ of Oranjemund Township (28 $12^{\prime} \mathrm{S}$ Lat, $15^{\circ} 58^{\prime} \mathrm{E}$ Long), SW Africa, 70 $\mathrm{m}$ from sea. Terrace now covered by ca. $1.5 \mathrm{~m}$ dune sand. Coll. and subm. 1965 by N. J. Guest, Consolidated Diamond Mines of SW Africa Ltd., P.O. Box 35, Oranjemund.

\section{GrN-4571. Oranjemund ORU ACI}

$38,100 \pm 500$

Shell fragments and sand.

\section{GrN-4572. Oranjemund ORU AC2}

Large mussel shells. 
present beach. Comment: outer layers etched off with dilute acid and inner carbonate dated. Young age shows that shell beds do not belong to fossil emerged beach, and provenance is unclear. Demonstrates caution necessary in interpreting such shell beds as old beaches.

\section{St. Lucia Lake series, Natal}

Borings in St. Lucia Lake (28 $0^{\prime} \mathrm{S}$ Lat, $32^{\circ} 25^{\prime} \mathrm{E}$ Long) on Natal coast for sedimentologic and palynologic studies. Core I, $400 \mathrm{~m} \mathrm{~N}$ of Hluhluwe R. mouth, under $1 \mathrm{~m}$ water, consists of $7 \mathrm{~m}$ gray clay; Core II at Hell's Gate $200 \mathrm{~m} \mathrm{~S}$ of $\mathrm{N}$ shore, and under $1.1 \mathrm{~m}$ water, consists of $70 \mathrm{~cm}$ dark-brown clay followed by gray clay to $8 \mathrm{~m}$. Coll. and subm. 1965 by E. M. van Zinderen Bakker.

\section{GrN-4533. St. Lucia I.1, No. 2802}

$2380 \pm 80$

430 B.C.

$\delta C^{1 s}=-14.8 \%$

Lake clay at 290 to $300 \mathrm{~cm}$ below bottom in Core I. Comment: pretreated with acid and cold alkali.

\section{GrN-4535. St. Lucia I.2, No. 2804}

$3960 \pm 60$ 2010 B.C.

Lake clay at 690 to $700 \mathrm{~cm}$ below bottom in Core I. Comment: pretreated with acid and cold alkali.

GrN-4536. St. Lucia II.1, No. 2866

$1820 \pm 85$

Lake clay at 180 to $190 \mathrm{~cm}$ below bottom in Core II. Comment: pretreated with acid and cold alkali.

GrN-4538. St. Lucia II.2, No. 2868

$2920 \pm 90$

970 в.c.

Lake clay at 780 to $790 \mathrm{~cm}$ below bottom in Core II. Comment: pretreated with acid and cold alkali.

General Comment (E.M.v.Z.B.): dates give good assessment of sedimentation rate and were thus of value for planning hydrology of area.

\section{GrN-4250. Umfolozi, Natal}

$$
\begin{array}{r}
4600 \pm 60 \\
2650 \text { B.c. } \\
\delta C^{13}=-27.8 \% o
\end{array}
$$

Piece of wooden $\log$ recovered at founding depth of a pier of new bridge over Umfolozi R. (28 $25^{\prime} \mathrm{S}$ Lat, $32^{\circ} 10^{\prime} \mathrm{E}$ Long), Natal. Subm. 1964 by Dept. of Transport, Rep. of South Africa. Comment: date indicated that river-bed sediment is not recent and probably stable enough for bridge foundation.

\section{Mochlaka series, Lesotho}

Boring in peat deposit at Mochlaka-Watuka $\left(29^{\circ} 20^{\prime} \mathrm{S}\right.$ Lat, $27^{\circ} 15^{\prime}$ E Long) alt: $1700 \mathrm{~m}$, in Lesotho for pollen analysis. Coll. and subm. 1966 by E. M. van Zinderen Bakker. 
GrN-4891. Mochlaka 1, No. 3307

Peat from $150 \mathrm{~cm}$ depth in core. Comment: pretreated with acid and cold alkali.

GrN-4890. Mochlaka 2, No. 3306

$4710 \pm 70$

2760 B.c.

$\delta C^{13}=-22.0 \%$ o

Peat from 385 to $400 \mathrm{~cm}$ depth in core. Comment: pretreated with acid and cold alkali.

General Comment: pollen content too low for analysis due to burning of peat on several occasions.

\section{Aliwal North series, Cape Province}

Boring in peat and clay formed round mineral spring at Aliwal North ( $30^{\circ} 42^{\prime} \mathrm{S}$ Lat, $26^{\circ} 42^{\prime} \mathrm{E}$ Long), Cape Province. Pollen diagram covers period between samples and shows several alternations of pure grassveld (Coetzee, 1967). Coll. by J. A. Coetzee and subm. 1962 by Coetzee and E. M. van Zinderen Bakker.

GrN-4012. Aliwal N 1, No. 1931a

$9660 \pm 150$

Peat at 500 to $510 \mathrm{~cm}$ depth. Pollen diagram shows warm and dry Karroid vegetation.

GrN-4011. Aliwal N 2, No. 2306

$12,600 \pm 110$

10,650 B.c.

Peaty clay at 920 to $940 \mathrm{~cm}$ depth. Pollen diagram indicates colder and humid climate with pure grassveld.

General Comment: alterations apparently correlate with Late-Glacial Interstadials in Europe.

GrN-5444. Welgevonden, Cape Province

$C^{14}=(2.0 \pm 0.8) \%$

$$
49,900+4100
$$

47,950 в.c.

Calcrete from $31 \mathrm{~m}$ depth in Borehole WV 27 on farm Welgevonden in Postmasburg area (28 $20^{\prime} \mathrm{S}$ Lat, $23^{\circ} 05^{\prime}$ E Long). Coll. by P. J. Smit and subm. 1967 by J. C. Vogel. Comment: calcrete at base of Pleistocene "Kalahari Beds", overlain by clay and thick Kalahari sands. Outer layers etched off with dilute acid and inner carbonate analyzed. Date is minimum because contamination by ground water could make date too young.

\section{GrN-5878. Langebaan, Cape Province}

$6410 \pm 45$ 4460 в.c.

$\delta C^{13}=0.0 \%$

Oyster dredged from surface of submerged shell bank, $\mathrm{S}$ end of Langebaan Lagoon (33 $11^{\prime} \mathrm{S}$ Lat, $18^{\circ} 06^{\prime} \mathrm{E}$ Long), $85 \mathrm{~km} \mathrm{~N}$ of Cape 
Town. Oysters do not live in lagoon today because Benguela current is too cold. Subm. 1964 by R. R. Inskeep. Comment: result suggests warmer water at this date.

\section{Rietvlei series, Cape Province}

In recent sediments at Rietvlei (33 $50^{\prime} \mathrm{S}$ Lat, $18^{\circ} 30^{\prime} \mathrm{E}$ Long) near Cape Town. H. Schalke made boring of ca. $20 \mathrm{~m}$ depth for palynologic study. Samples coll. 1967 and subm. by E. M. van Zinderen Bakker.

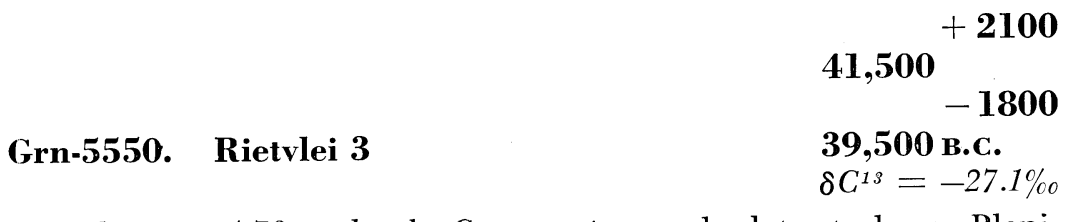

Root layer at $4.73 \mathrm{~m}$ depth. Comment: sample dates to lower Pleniglacial period of Europe. Pretreated with acid only.

GrN-5551. Rietvlei 5

$$
\delta C^{13}=-25.5 \%
$$

$3.5 \mathrm{~g}$ charcoal from $7.01 \mathrm{~m}$ depth. Comment: pretreated with acid only.

General Comment: pollen analysis done by H. Schalke but no comment available. Since correlation with former sea levels is possible, study of vegetation is most important.

\section{Hangklip series, Cape Province}

Between Rooi Els and Cape Hangklip $\left(34^{\circ} 20^{\prime} \mathrm{S}\right.$ Lat, $18^{\circ} 50^{\prime} \mathrm{E}$ Long) W Cape Prov., deep peat deposit occurs on elevated vlei. Cored for pollen analysis by R. R. Inskeep and A. Hall and samples subm. 1964 by Inskeep, Dept. of Archaeol., Univ. of Cape Town.

\section{GrN-4585. Hangklip 1}

$$
\begin{aligned}
& \quad \mathbf{3 6 0} \pm \mathbf{3 0} \\
& \text { A.D. } \mathbf{1 5 9 0} \\
& \delta C^{13}=-28.7 \%
\end{aligned}
$$

Peat at $45 \mathrm{~cm}$ depth. Comment: pretreated with acid and alkali.

GrN-4649. Hangklip 2

$2560 \pm 35$

610 B.C.

$$
\delta C^{13}=-28.3 \%
$$

Peat at $75 \mathrm{~cm}$ depth. Comment: pretreated with acid and alkali.

\section{GrN-4473. Hangklip 3}

$6080 \pm 50$

4130 B.C.

Peat at $230 \mathrm{~cm}$ depth. Comment: pretreated with acid and alkali.

\section{GrN-4586. Hangklip 4}

$$
\begin{gathered}
11,140 \pm 65 \\
9190 \text { B.c. } \\
\delta C^{13}=-28.9 \% \%
\end{gathered}
$$

Peat from $360 \mathrm{~cm}$ depth. Comment: pretreated with acid and alkali. 
General Comment: pollen analysis started by Hall in 1964 but not continued. Unfortunate that this continuous record of Holocene flora in W Cape is not being studied.

\section{Atlantic and Indian Oceans}

\section{Hormuz series, Persian Gulf}

Sediment core from Strait of Hormuz (ca. $26^{\circ} 30^{\prime} \mathrm{N} \mathrm{Lat,} 56^{\circ} 0^{\prime} \mathrm{E}$ Long), Persian Gulf, containing calcium carbonate and organic material (Welte and Eberhardt, 1968). Samples subm. 1965 by D. H. Welte, Univ. of Würzburg, Germany.

\section{GrN-4861. Hormuz $10 \mathrm{~cm}$ organic}

$$
\begin{array}{r}
1940 \pm 200 \\
\delta C^{1 s}=-19.5 \%
\end{array}
$$

Organic fraction of core at $10 \mathrm{~cm}$ depth extracted with alkali after removal of carbonate with dilute acid.

\section{GrN-4864. Hormuz $10 \mathrm{~cm}$ carbonate}

Carbonate fraction of above sample.

GrN-4862. Hormuz 150 cm organic

$$
\begin{array}{r}
\mathbf{1 9 1 0} \pm \mathbf{5 0} \\
\delta C^{1 s}=-19.3 \%
\end{array}
$$

Organic fraction of core at 150 to $160 \mathrm{~cm}$ depth, extracted with alkali after removal of carbonate.

\section{GrN-4865. Hormuz 150 cm carbonate}

$$
\begin{array}{r}
7420 \pm 65 \\
\delta C^{1 s}=+0.4 \% 0 \\
\mathbf{8 7 6 0} \pm \mathbf{1 0 0} \\
\delta C^{13}=-20.4 \% 0
\end{array}
$$

Carbonate fraction of above sample.

GrN-4863. Hormuz $350 \mathrm{~cm}$ organic

Organic fraction of core at 350 to $360 \mathrm{~cm}$ depth, extracted with alkali after removal of carbonate.

\section{GrN-4866. Hormuz 350 cm carbonate}

$$
12,350 \pm 145
$$

Carbonate fraction of above sample.

$$
\delta C^{13}=+0.7 \%
$$

General Comment: older dates of carbonate fractions imply that calcium carbonate was transported prior to final sedimentation. Organic material, presumably derived from plankton, should give date of sedimentation proper. Predominance of even $n$-paraffins in range $C_{13}$ to $C_{21}$ observed in this core.

\section{Tananarive series, Madagascar}

Two peat cores from moors formed by lava flow in Itasy volcano area, $75 \mathrm{~km} \mathrm{~W}$ of Tananarive $\left(18^{\circ} 52^{\prime} \mathrm{S}\right.$ Lat, $47^{\circ} 30^{\prime} \mathrm{E}$ Long) for pollen analysis (Straka, 1960; de Waard and Straka, 1961). Coll. and subm. 1958 by $\mathrm{H}$. Straka, Botan. Inst., Univ. Kiel, Germany. 
GrN-2197. Marais d'Ifanja

Peat at 780 to $800 \mathrm{~cm}$ depth in $810 \mathrm{~cm}$ core (B 25) in round depression formed in Marais d'Ifanja at $1060 \mathrm{~m}$ alt $\mathrm{W}$ of Tananarive, $\mathrm{S}$ of Sanganore Sud. Comment: pretreated with acid only.

GrN-2804. Lake Itasy

$8505 \pm 90$

6555 B.c.

Peat at 900 to $930 \mathrm{~cm}$ depth in $1050 \mathrm{~cm}$ core (B 127) in small bay S of Lake Itasy, E of Soavinandriana at $1230 \mathrm{~m}$ alt. Comment: pretreated with acid only.

General Comment: pollen analysis still in progress. Dates show $15 \mathrm{~cm}$ and $10 \mathrm{~cm}$ peat growth, respectively, per century.

GrN-5192. Ampoza, Madagascar, No. M13932

$$
\begin{gathered}
2365 \pm 35 \\
\mathbf{7 1 5} \text { в.c. } \\
\delta C^{1 s}=-21.3 \%
\end{gathered}
$$

Humerus of extinct giant lemur (Palaeopropithecus maximus) from

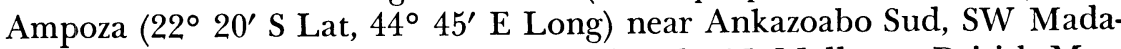
gascar. Coll. 1929 by E. I. White and subm. by T. Molleson, British Mus. (Nat. Hist.), London for A. C. Walker, Uganda. Comment: bone collagen dated. Maximum date for extinction, see also Mahé (1965).

\section{Vema Seamount series, Atlantic Ocean}

Calcareous concretions ca. $6 \mathrm{~cm}$ diam., with spherical layering; some with pebble nuclei occurring on surface of Emerson R. Plateau, a wavecut terrace at $-73 \mathrm{~m}$ on Vema Seamount ( $31^{\circ} 37^{\prime} \mathrm{S}$ Lat, $08^{\circ} 18^{\prime} \mathrm{E}$ Long), $900 \mathrm{~km} \mathrm{NW}$ of Cape Town (Simpson and Haydorn, 1965). Coll. 1964 and subm. 1965 by E. S. W. Simpson, Dept. Geol., Univ. of Cape Town.

\section{GrN-4792. Vema 1 inner}

Inner $27 \mathrm{~g}$ of Ball 1.

\section{GrN-4789. Vema 1 outer}

Outer $27 \mathrm{~g}$ of Ball 1.

\section{GrN-4732. Vema 4 inner}

Inner $30 \mathrm{~g}$ of Ball 4 .

GrN-4733. Vema 4 outer

Outer $57 \mathrm{~g}$ of Ball 4.
$690 \pm 50$

A.D. 1260

$\delta C^{1 s}=-1.1 \%$

$$
\begin{array}{r}
290 \pm 40 \\
\text { A.D. } 1660 \\
\delta C^{15}=-1.8 \% \text { o }
\end{array}
$$

$$
\begin{array}{r}
\mathbf{1 0 0 0} \pm \mathbf{3 0} \\
\text { A.D. } 950 \\
\delta C^{1 s}=-1.2 \% 0 \\
\mathbf{7 2 0} \pm \mathbf{4 5} \\
\text { A.D. } 1230
\end{array}
$$

General Comment: all samples etched with dilute acid; the carbonate dated. Balls apparently no longer growing. Date of beginning and end 
of growth depends on whether weight or radius increases linearly with time; derived dates are:

Ball 1 (by radius): 900 to 250 B.P.: $650 \mathrm{yr}$
(by weight): 750 to 200 B.P.:550 yr.
Ball 4 (by radius): 1200 to 650 B.P.:550 yr
(by weight): 1100 to 550 B.P.:550 yr.

Balls thus attain maximum size after ca. $600 \mathrm{yr}$ and are probably younger than terrace.

\section{Marion Island series}

Boring in peat mire behind Marion House, close to shore, on Marion I. ( $46^{\circ} 55^{\prime} \mathrm{S}$ Lat, $37^{\circ} 50^{\prime} \mathrm{E}$ Long) for pollen analysis. Ca. $3 \mathrm{~m}$ peat lies on black lava flow at site. Coll. and subm. 1963 by E. M. van Zinderen Bakker.

\section{GrN-4153. Marion 1, No. 2697}

$$
\begin{gathered}
2910 \pm 60 \\
960 \text { в.c. } \\
\delta C^{13}=-27.1 \% 0
\end{gathered}
$$

Peat from 190 to $200 \mathrm{~cm}$ depth in boring. Comment: pretreated with acid and cold alkali.

\section{GrN-4152. Marion 2, No. 2696}

$4000 \pm 65$ 2050 B.C.

Peat from 280 to $295 \mathrm{~cm}$ depth in boring at same site. Comment: pretreated with acid and cold alkali. Gives minimum date for lava. Since no glacial or periglacial features have been found on lava, it must be Post-Glacial. Compare K-1063: $3180 \pm 120$ B.P. for bottom of mire at Junior's Kop.

General Comment: pollen diagram shows vegetation similar to today.

\section{Prince Edward Island series}

Boring in peat deposit on lava on Prince Edward I. (46 $38^{\prime} \mathrm{S}$ Lat, $37^{\circ} 55^{\prime}$ E Long) for pollen analysis. Coll. 1966 by H. Schalke and subm. by E. M. van Zinderen Bakker. Pollen diagram prepared by H. Schalke.

\section{GrN-4893. Prince Edward 1, No. 78-3593}

Peat at 190 to $200 \mathrm{~cm}$ depth in boring, just below upper volcanic ash layer and peak in lowland indicators in pollen diagram. Comment: acid pretreatment only.

\section{GrN-4892. Prince Edward 2, No. 80-3595}

$5830 \pm 70$ 3880 B.C.

$$
\delta C^{13}=-26.2 \%
$$

Peat at 315 to $330 \mathrm{~cm}$ depth in boring, dating lowest of 3 volcanic ash layers. Comment: acid pretreatment only. Minimum age for lava flow which is apparently early Post-Glacial (compare Marion I. series above.) 
General Comment (v.Z.B.): pollen diagram shows no change in vegetation.

\section{ARCHAEOLOGIC SAMPLES}

\section{Southern Africa}

A. Middle Stone Age

\section{Redcliff series, Rhodesia}

Sediment-filled cave exposed in NW face of limestone quarry of Rhodesian Iron and Steel Co. at Redcliff (19 $01^{\prime} \mathrm{S}$ Lat, $29^{\circ} 46^{\prime} \mathrm{E}$ Long), $13 \mathrm{~km} \mathrm{~S}$ of Que Que, Rhodesia, was excavated 1964 by C. K. Brain and C. K. Cooke (Brain and Cooke, 1967). Large quantities of stone artifacts (Middle Stone age) and bone were recovered from more than $17 \mathrm{~m}$ of deposit. Samples subm. 1968 by C. K. Brain, Transvaal Mus., Pretoria.

GrN-5679. Redeliff 1

\section{GrN-5858. Redcliff 2}

$\mathbf{4 1 , 8 0 0}$

$$
+5000
$$

39,850 в.c.

$$
-3000
$$

Two samples of charred bone from Layer W in Sec. VI, $15 \mathrm{ft}(455$ $\mathrm{cm}$ ) below datum line in Profile B, near top of Rhodesian Stillbay succession. Comment: both samples pretreated as for charred bone and alkali soluble fraction dated. Combining results give 41,000 $\begin{array}{r}+2000 \\ -1500\end{array}$ B.P., in good agreement with Isotopes' dates I-3727: $35,500 \pm 2700$ B.P. for $14 \mathrm{ft}$ level and I-3728: $>39,900$ B.P. for $16 \mathrm{ft}$ level, but much older than expected.

\section{GrN-5347. Otjiseva, South West Africa}

$4940 \pm 70$ 2990 B.C.

$$
\delta C^{13}=-2.1 \%
$$

Calcrete incrusation on bone of Boskop-type skeleton found 1964 at $30 \mathrm{~cm}$ depth in alluvium on farm Otjiseva $\left(22^{\circ} 18^{\prime} \mathrm{S}\right.$ Lat, $16^{\circ} 56^{\prime} \mathrm{E}$ Long), $40 \mathrm{~km} \mathrm{~N}$ of Windhoek, South West Africa. Coll. and subm. 1967 by W. Sydow, P.O. Box 2475, Windhoek. Comment: as no collagen was left in bone, only carbonate could be dated. Result is minimum date for incrustation and skeleton is probably much older. Cranium closely resembles original Boskop skull. No correction for isotope fractionation.

\section{Lion Cavern series, Swaziland}

Lion Cavern on $\mathrm{S}$ end of steep scarp face of small hematite hill, called Lion Peak, at Ngwenya Iron Mine (26 $16^{\circ} \mathrm{S}$ Lat, $31^{\circ} 02^{\prime} \mathrm{E}$ Long), $24 \mathrm{~km} \mathrm{NW}$ of Mbabane, Swaziland, was excavated 1965 and 1966 by 
P. Beaumont. Cavern, $9 \mathrm{~m}$ deep, was artificially formed by removal of specularite-rich hematite and floor covered with over $3.3 \mathrm{~m}$ deposit which yielded many artifacts belonging to middle stage of Middle Stone age, from $2.4 \mathrm{~m}$ to the artificial bedrock (Dart and Beaumont, 1969a). Assemblage contains points formed by convergent flaking and coarse dolerite mining tools. Samples coll. and subm. by P. Beaumont, Bernard Price Inst. for Palaeontol. Research, Univ. of Witwatersrand, Milner Park, Johannesburg.

\section{GrN-5020. Lion Cavern 1}

$28,130 \pm 260$

26,180 в.c.

$\delta C^{13}=-24.1 \%$

Charcoal nodules from ash layer at 244 to $290 \mathrm{~cm}$ on artificial bedrock, Sq. B.C. 7-11.

GrN-5313. Lion Cavern 2

41,250 B.c.

$\delta C^{13}=-24.8 \%$

Charcoal nodules from lower level of $90 \mathrm{~cm}$ Middle Stone age stratum, at 335 to $410 \mathrm{~cm}$ below datum and near bedrock, in Sq. A 8-11; closer to mouth of cavern than Sample 1.

General Comment: dates prove extensive mining for iron ore (red ocher) since 41,000 B.c. Two further dates from same cavern, but farther away from hill face, are Y-1827: 22,280 \pm 400 B.P. and Y-1713: $9640 \pm 80$ B.P. (Radiocarbon, 1969, v. 11, p. 645) indicating that mining continued at this oldest mine in world for over $30,000 \mathrm{yr}$.

Charcoal from upper levels of $120 \mathrm{~cm}$ thick Middle Stone age stra tum, underlying $60 \mathrm{~cm}$. Later Stone age stratum, at Sibebe Shelter on crest of Sibebe Hill (26 $16^{\prime} \mathrm{S}$ Lat, $31^{\circ} 15^{\prime}$ E Long), $8 \mathrm{~km}$ NE of Mbabane, Swaziland (Cut No. B.P. 27.66). Assemblage includes well-flaked, bifaced points (spear and arrowheads) and represents transitional stage between Middle Stone age and 2nd Intermediate. Coll and subm. 1967 by P. Beaumont. Comment: older than expected for such advanced techniques, as are all dates in this section.

\section{Bushman Rock series, Transvaal}

Bushman Rock Shelter (24 $35^{\prime} \mathrm{S}$ Lat, $30^{\circ} 38^{\prime}$ E Long), excavated 1965 near Echo Caves in Ohrigstad dist. yielded ample material for dating. Sequence down to $244 \mathrm{~cm}(8 \mathrm{ft})$ divided into 43 layers, containing undisturbed Middle Stone age artifacts from Layers 43 to 28, Later Stone age with derived Middle Stone age artifacts in decreasing quantity from Layers 27 to 7, and mixed Later Stone age and Iron age remains in uppermost layers (Louw et al., 1969). Samples coll. 1965 by A. W. Louw and selected 1966 by Louw, Mason, and Vogel. 
GrN-4855. Bushman Rock 41 $>47,500$

Charcoal from Layer 41 at $225 \mathrm{~cm}$ depth in Sq. 7B containing Middle Stone age artifacts.

GrN-5116. Bushman Rock 38

$$
>\mathbf{5 3 , 0 0 0}
$$

Charcoal from Layer 38 at $200 \mathrm{~cm}$ depth in Sq. 7B containing Middle Stone age artifacts.

\section{GrN-4816. Bushman Rock 28a}

$$
\begin{aligned}
& 12,510 \pm 105 \\
& 10,560 \text { в.C. }
\end{aligned}
$$$$
\delta C^{13}=-24.9 \%
$$

Wood from top of gravel layer (Layer 28) at $142 \mathrm{~cm}$ depth in Sq. 7C, representing uppermost undisturbed Middle Stone age remains.

\section{GrN-5873. Bushman Rock 28b}

$$
\begin{gathered}
12,470 \pm 145 \\
10,520 \text { B.C. } \\
\delta C^{13}=-24.7 \% 0
\end{gathered}
$$

Small wood sample from Layer 28 at $142 \mathrm{~cm}$ depth in Sq. 8B.

\section{GrN-4815. Bushman Rock 27}

$$
\begin{gathered}
12,160 \pm 95 \\
10,210 \text { B.C. } \\
\delta C^{13}=-22.0 \%
\end{gathered}
$$

Charred wood from Layer 27 (Bed Z2) at $137 \mathrm{~cm}$ depth in Sq. 7C. Bottom-most layer containing Later Stone age artifacts.

\section{GrN-4814. Bushman Rock 21}

$$
\begin{gathered}
12,090 \pm 95 \\
10,140 \text { B.c. } \\
\delta C^{13}=-23.1 \% o
\end{gathered}
$$

Charcoal in soft brown sand, Layer 21, at 99 to $107 \mathrm{~cm}$ depth in Sq. 7C containing Later Stone age and derived Middle Stone age artifacts.

\section{GrN-4813. Bushman Rock 12}

$$
\begin{gathered}
\mathbf{9 9 4 0} \pm \mathbf{8 0} \\
\mathbf{7 9 9 0} \text { B.c. } \\
\delta C^{13}=-24.9 \% \%
\end{gathered}
$$

Charred bones from Layer 12 at 61 to $69 \mathrm{~cm}$ depth in Sq. 7C containing Later Stone age and derived Middle Stone age artifacts. Comment: pretreated by boiling with $\mathrm{HCl}$ and extracting humic material with warm alkali solution.

GrN-4854. Bushman Rock 9

$9510 \pm 55$ 7560 B.C.

$$
\delta C^{1 s}=-23.0 \%
$$

Charcoal from Layer 9 at $30 \mathrm{~cm}$ depth in Sq. $7 \mathrm{C}$, containing Later Stone age artifacts.

\section{GrN-5874. Bushman Rock 3}

$$
\begin{gathered}
\mathbf{9 5 7 0} \pm \mathbf{5 5} \\
\mathbf{7 6 2 0} \text { B.c. } \\
\delta C^{1 s}=-24.4 \% \%
\end{gathered}
$$

Charcoal from Layer 3 of cemented patch P2 at $15 \mathrm{~cm}$ depth in Sq. 7B, containing Later Stone age artifacts and some intrusive objects of Iron age occupation. 
General Comment: Later Stone age assemblage from Layers 3 to 27, dated 9540 to 12,160 B.P., resemble Middle Smithfield culture as found at Uitkomst Cave, Bed 1 (Y-1324: 11,250 \pm 200 в.P.). Middle Stone age industry has many bifacially trimmed flakes, including well-formed points and also handaxes, and can be assigned to middle stage of Middle Stone age. Results shift this period in Transvaal back to unexpectedly early date of $>53,000$ B.P. Since no variation in typology is evident between Layers $41 / 38$ and 28, it was suspected that wood of $\mathrm{GrN}-4816$ was intrusive from Later Stone occupation above. Thus second sample from Layer 28 (GrN-5873) was measured, with same result. It, nevertheless, seems more probable that this too was intrusive than that industry existed for over $40,000 \mathrm{yr}$ without change. Since Louw's excavation, artifacts similar to Early Pietersburg assemblage at Cave of Hearths (C-926: 16,811 \pm 960 B.P.) have been discovered below Layer 43, thus suggesting much earlier date for Early Pietersburg culture.

GrN-4208. Florisbad 1, Orange Free State, No. $2702>\mathbf{4 8 , 9 0 0}$

Sandy clay with few per cent organic matter from bottom dark layer at about $5.60 \mathrm{~m}$ depth (Peat I) in 1952 excavation at Florisbad Spring (28 $46^{\prime} \mathrm{S}$ Lat, $26^{\circ} 05^{\prime} \mathrm{E}$ Long), $48 \mathrm{~km}$ NW of Bloemfontein, Orange Free State. This layer contains chopper tool industry (Florisbad culture) and fossils of extinct animals (Meiring, 1956). Florisbad skull excavated by Dreyer in 1932 came from bottom of small eye below Dark Layer I, sand filling of which was sealed by green sand layer overlying it so that stratigraphic position is uncertain (Dreyer, 1938). Pollen spectrum suggests Karroo vegetation and thus drier climate than today (van Zinderen Bakker, 1955). Coll. and subm. 1963 by E. M. van Zinderen Bakker. Comment: $150 \mathrm{~g}$ pretreated with acid and cold alkali gave $4 \mathrm{~g}$ carbon for analysis. Cf. C-850: $>41,000$ B.P., L-271 B: $>35,000$ B.P., Y-103: $>44,000$ B.P. for same layer.

\section{Montagu series, Cape Province}

Two further samples dated from cave ca. $8 \mathrm{~km} \mathrm{E}$ of Montagu (33० $50^{\prime} \mathrm{S}$ Lat, $20^{\circ} 10^{\prime} \mathrm{E}$ Long), Cape Province (cf. Vogel and Waterbolk, 1967). Coll. 1964 by C. Keller and subm. by J. D. Clark, Dept. of Anthropol., Univ. of California, Berkeley.

\section{GrN-5123. Montagu MSA 43}

$19,100 \pm 110$ 17,150 в.с.

$$
\delta C^{13}=-24.7 \%
$$

Charcoal and black soil from 175 to $180 \mathrm{~cm}$ depth in Sq. G20 between Surfaces 6 and 7, with Late Middle Stone age assemblage (Howie-
son's Poort industry?).

GrN-5124. Montagu MSA 44

Charcoal from $178 \mathrm{~cm}$ depth in Sq. F35 just below Surface 7, with Late Middle Stone age assemblage. 
General Comment: additional samples measured because MSA 46 (GrN4728: $45,900 \pm 2100$ в.P.) gave unexpectedly high age for industry. $\mathrm{GrN}$ 5123 in accordance with expectation (cf. I-1844: 18,740 \pm 320 B.P. for Howieson's Poort), but other dates suggest Middle Stone age started before 45,900 в.P. and probably before 50,800 B.P. unless MSA 44 derives from underlying Early Stone age levels. Compare other early Middle Stone age dates, above.

\section{Robberg series, Cape Province}

Re-excavation of Wagenaar's cave on Robberg peninsula (34 $04^{\circ} \mathrm{S}$ Lat, 23 23' E Long), Plettenberg Bay, on S coast, by R. R. Inskeep has provided new evidence on cultural material accumulated since Middle Stone age times. Coll. by R. R. Inskeep and subm. 1968 by J. C. Vogel.

\section{GrN-5889. Robberg, C 6}

$18,660 \pm 110$ 16,710 в.c. $\delta C^{13}=+4.3 \%$

Shell fragments from $180 \mathrm{~cm}$ depth in layer containing sparse Middle Stone age artifacts. Comment: outer layers removed with dil. acid and inner carbonate dated. Age similar to that for Howieson's Poort (I-1844: $18,740 \pm 320$ B.P.), but artifacts are nondescript. For accuracy of such shell dates, see Matjes R. series below.

\section{GrN-5702. Robberg, C 8}

$$
\begin{array}{r}
2925 \pm \mathbf{3 5} \\
975 \text { в.c. } \\
\delta C^{13}=-24.2 \% \text { o }
\end{array}
$$

Charcoal from $60 \mathrm{~cm}$ depth in cave mouth shell midden in Later Stone age (Wilton) context with macrolithic quarzite and ground slate industry. Comment: due to smallness of sample pretreated with acid only. Because age is not high, contamination cannot be serious.

GrN-5715. Robberg, C 10

$2540 \pm 50$ 590 B.c.

Charcoal fragments from $50 \mathrm{~cm}$ depth in Later Stone age layer with microlithic points. Comment: due to smallness of sample pretreated with acid only. Contamination, however, cannot be serious.

\section{GrN-5703. Robberg, C 11}

$$
1930 \pm 60
$$

\section{A.D. 20}

$\delta C^{13}=-24.2 \%$

Charcoal from $40 \mathrm{~cm}$ depth, just below 1st pottery in Later Stone age level. Comment: due to smallness of sample pretreated with acid only. Provides date for introduction of pottery into area.

\section{GrN-5803. Melkbos C12, Cape Province}

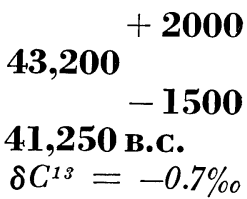

Shells from consolidated beach rock assoc. with $4 \mathrm{~m}$ emerged beach containing late Middle Stone age artifacts $6 \mathrm{~km} \mathrm{~N}$ of Melkbosstrand (33 
$45^{\prime}$ S Lat, $18^{\circ} 25^{\prime}$ E Long), Table Bay. Coll. and subm. 1967 by R. R. Inskeep. Comment: since low $\mathrm{C}^{14}$ content $(0.46 \pm 0.1 \%)$ can be due to contamination, date only minimum. In accordance with other dates in sec., Middle Stone age is older than 40,000 B.P.

\section{GrN-5804. Hout Bay C13, Cape Province}

Whole mytilus shells assoc. with apparently post Middle Stone age artifacts in sand overlying ca. $6 \mathrm{~m}$ emerged beach and covered by ca. $4 \mathrm{~m}$ sand dune just $\mathrm{W}$ of harbour at Hout Bay $\left(34^{\circ} 03^{\prime} \mathrm{S}\right.$ Lat, $18^{\circ} 22^{\prime}$ E Long), Cape Peninsula. Coll. and subm. by R. R. Inskeep. Comment: since low $\mathrm{C}^{14}$ content $(0.29 \pm 0.09 \%)$ can be due to contamination, date only minimum. Again proving high antiquity of Middle Stone age, see above.

\section{B. Later Stone Age}

Rose Cottage series, Orange Free State

Rose Cottage cave, near Ladybrand (29 $19^{\circ} 5^{\prime} \mathrm{S}$ Lat, $27^{\circ} 30^{\prime} \mathrm{E}$ Long), Orange Free State (Malan, 1952) re-excavated 1962 by P. Beaumont, contains $1.4 \mathrm{~m}$ Wilton and Pre-Wilton (Later Stone age), $2.1 \mathrm{~m}$ sterile and $2.3 \mathrm{~m}$ Magosian (terminal Middle Stone age) deposit. Samples coll. by P. Beaumont and subm. 1967 by R. J. Mason, Univ. of Witwatersrand, Milner Park, Johannesburg.

\section{GrN-5300. Rose Cottage 3}

$25,640 \pm 220$

23,690 B.C.

$\delta C^{13}=-22.3 \%$

Charcoal from $176 \mathrm{~cm}$ depth in Sq. Jf, $30 \mathrm{~cm}$ below Pre-Wilton, in sterile layer overlying Magosian.

\section{GrN-5299. Rose Cottage 2}

$6850 \pm 45$ 4900 B.c. $\delta C^{1 s}=-23.3 \%$

Charcoal from 36 to $46 \mathrm{~cm}$ depth, Sq. Ld, in Wilton Phase 2 layer.

\section{GrN-5298. Rose Cottage}

$$
\begin{array}{r}
\mathbf{1 1 0 0} \pm \mathbf{3 0} \\
\text { A.D. 850 } \\
\delta C^{13}=-24.0 \% o
\end{array}
$$

Charcoal from 20 to $25 \mathrm{~cm}$ depth, Sq. Le, in base of Wilton Phase 3 layer which also contained impressed pottery suggesting contemporaneous Iron Age groups.

General Comment: Sample 3 gives unexpectedly high date for Pre-Wilton and Magosian. South African Magosian must thus be much older than at Pomongwe, Rhodesia (SR-11: 15,800 \pm 200 B.P., Robins and Swart, 1964) but this is in keeping with other high ages for Middle Stone age, above. Date for Magosian level at $3.8 \mathrm{~m}$ of $>50,000$ B.P. (SR-116) confirms this high dating. Results for Wilton culture as expected. 
Matjes River series, Cape Province

Stratigraphic series of shell and charcoal samples from Matjes $\mathrm{R}$. rock shelter ( $34^{\circ} 01^{\prime} \mathrm{S}$ Lat, $23^{\circ} 25^{\prime} \mathrm{E}$ Long) near Plettenberg Bay, Cape Province, coll. 1964 by R. R. Inskeep and H. and J. Deacon at intersection of 2 existing trenches excavated in 1950's by Louw et al. (Louw, 1960). Deposit consists mainly of shell midden in which several Later Stone age horizons were identified. Subm. 1964 by R. R. Inskeep.

GrN-5061. Matjes R. PT 10, shell

GrN-5871. Matjes R. PT 10, charcoal

Shell and charcoal from lowest level.

GrN-5886. Matjes R. PT 13, shell

\section{GrN-5872. Matjes R. PT 13, charcoal}

Shell and charcoal from next lowest level.

\section{GrN-5887. Matjes R. PT 17, shell}

Shell from higher level.

\section{GrN-5888. Matjes R. PT 21, shell}

Shell from uppermost level.
$9780 \pm 60$

7830 в.C.

$\delta C^{13}=+0.23 \%$

$10,030 \pm 55$ 8080 B.C.

$\delta C^{13}=-25.5 \%$

$9450 \pm 55$

7500 B.c.

$\delta C^{1 s}=+0.42 \%$

$9580 \pm 85$

7630 B.c.

$\delta C^{13}=-23.3 \%$ o

$7050 \pm 45$

$\mathbf{5 1 0 0}$ в.c.

$\delta C^{13}=+0.88 \%$

$3555 \pm 35$

1605 B.C.

$\delta C^{1 s}=-0.20 \%$

General Comment: samples cannot be correlated directly with Louw's cultural levels; coll. to check validity of dates on shell from middens and for palaeotemperature work. PT 10 and PT 13 show shell to be 250 and $130 \mathrm{yr}$ too young, respectively, corresponding to $1.3 \%$ and $0.7 \%$ recent contamination. Thus, although such shells may give slightly too young dates, they can be used with confidence when charcoal is lacking. Shelter was occupied from somewhat before 8100 B.c. to at least 1600 B.c.

\section{GrN-5023. Castle Quarry, Swaziland}

$$
\begin{gathered}
2860 \pm 35 \\
910 \text { B.c. } \\
\delta C^{13}=-24.3 \% \%
\end{gathered}
$$

Charcoal from base of deposit in ancient quarry for iron ore (red ocher) at $170 \mathrm{~cm}$ depth assoc. with assemblage representing middle phase of Later Stone age near Castle Peak, Ngwenya Iron Mine $\left(26^{\circ} 12^{\prime} \mathrm{S}\right.$ Lat, $31^{\circ} 02^{\prime} \mathrm{E}$ Long), $24 \mathrm{~km} \mathrm{NW}$ of Mbabane, Swaziland. Coll. and subm. 1966 by P. Beaumont. 


\section{GrN-5021. Banda Cave, Swaziland}

$$
\begin{aligned}
& \mathbf{1 6 5 0} \pm \mathbf{4 0} \\
& \text { A.D. 300 } \\
& \delta C^{13}=-24.4 \% \%
\end{aligned}
$$

Scattered charcoal from ca. $38 \mathrm{~cm}$ depth in deposit in natural cave at Ngwenya Iron Mine ( $26^{\circ} 12^{\prime} \mathrm{S}$ Lat, $31^{\circ} 02^{\prime} \mathrm{E}$ Long), $24 \mathrm{~km} \mathrm{NW}$ of Mbabane, Swaziland. Deposit contained assemblage attributed to early stage of Later Stone age overlain by Iron age remains. Coll. and subm. 1966 by P. Beaumont. Comment: much younger than Y-1714: $5890 \pm$ 80 в.P. (Radiocarbon, 1969, v. 11, p. 645) for more localized lower level. Charcoal presumably mostly of Iron age date.

\section{Castle Cavern series, Swaziland}

$$
\text { C. Iron Age }
$$

Cavern formed by prehistoric mining of specularite-rich hematite (red ocher) near summit of Castle Peak, at $\mathrm{S}$ end of Ngwenya Range, Ngweny Iron Mine (26 $16^{\prime} \mathrm{S}$ Lat, $31^{\circ} 02^{\prime} \mathrm{E}$ Long), $24 \mathrm{~km} \mathrm{NW}$ of Mbabane, Swaziland, contained $140 \mathrm{~cm}$ Early Iron age deposit, including thick potsherds, some of which show necks with broad horizontal grooves just below rim, and stone mining tools (Dart and Beaumont, 1969b). Excavated 1965 and subm. by P. Beaumont.

\section{GrN-5022. Castle Cavern 1}

$$
\begin{array}{r}
\mathbf{1 5 3 5} \pm \mathbf{3 0} \\
\text { A.D. 415 } \\
\delta C^{13}=-24.2 \% 0
\end{array}
$$

Charcoal nodules from hearths at 90 to $120 \mathrm{~cm}$ depth in Strips A-B (BP 10.65).

\section{Grn-5315. Castle Cavern 2}

$$
\begin{array}{r}
1550 \pm \mathbf{3 0} \\
\text { A.D. } 400 \\
\delta C^{13}=-24.7 \% o
\end{array}
$$

Charcoal nodules from hearths at 60 to $90 \mathrm{~cm}$ depth in Strip B (BP $10.65)$.

General Comment: agrees well with Y-1712: $1550 \pm 60$ B.P. (120 to 130 $\mathrm{cm}$ ) and Y-1995: $1430 \pm 100$ в.P. (30 to $60 \mathrm{~cm}$ ) (Radiocarbon, 1969, v. 11, p. 644). Earliest dates for Iron age $S$ of Limpopo R.

\section{Eros series, South West Africa}

Iron age deposit, 35 to $40 \mathrm{~cm}$, in Eros Shelter, Klein Windhoek (22 $33^{\prime} \mathrm{S}$ Lat, $17^{\circ} 05^{\prime}$ E Long), South West Africa, excavated by H. R. MacCalman. Subm. 1967 by H. R. MacCalman, State Mus., Windhoek.

GrN-5296. Eros 1

$345 \pm 30$

\section{A.D. 1605}

Charcoal (B1541/B2ii) from upper hearth $15 \mathrm{~cm}$ below surface.

$$
\delta C^{13}=-24.0 \%
$$

\section{GrN-5297. Eros 2}

$1745 \pm 35$

A.D. 205

$\delta C^{13}=-24.2 \%$

Charcoal (B1541/B2iii) from hearth at $35 \mathrm{~cm}$ depth on bedrock. 
General Comment: both samples pretreated with acid and alkali. First Iron age dates for South West Africa. From calibration curve (Fig. 1) historical date for Eros 1 can lie anywhere between A.D. 1475 and A.D. 1615.

GrN-5138. Rooiberg, Transvaal

A.D. 1515

$435 \pm 45$

$\delta C^{13}=-25.6 \%$

Part of $\log$ found by early prospectors in Iron age mine shaft with wooden hafted adze at Rooiberg Tin Mines (24 $40^{\prime} \mathrm{S}$ Lat, $27^{\circ} 40^{\prime} \mathrm{E}$ Long). Ca. $70 \mathrm{~km} \mathrm{~W}$ of Nylstroom, Transvaal (Mason, 1962). Coll. ca. 1905 and subm. 1967 by R. J. Mason. Comment: de Capelle expedition purchased tin bars on E coast in 1725, possibly from this area. Date is intermediate between those for Mapungubwe in $\mathrm{N}$ and Stone Wall culture in S. Historical date derived from calibration curve (Fig. 1) is A.D. 1445 \pm 25 .

\section{Vergenoegd (Kurrichane) series, Transvaal}

In Central and $S$ Transvaal, from Zeerust in $\mathrm{W}$ to Lydenburg in $\mathrm{E}$, thousands of stone-walled settlements belonging to Iron age people have been identified (Mason, 1968). This culture was apparently destroyed in 1820 's by Moselikatse. Due to fluctuations of atmospheric radiocarbon concentration during the last $500 \mathrm{yr}$ (de Vries, 1958), dating with $\mathrm{C}^{14}$ is sometimes not unique. By measuring a stratigraphic sequence, however, most probable historic date can be deduced by successive elimination of different possibilities for each radiocarbon date. This has been attempted at Vergenoegd (25 $40^{\prime} \mathrm{S}$ Lat, $26^{\circ} 10^{\prime} \mathrm{E}$ Long), Zeerust Dist., Transvaal, and Olifantspoort (below). Site id. by Seddon (1966) as Kurrichane (or Kaditshwene) visited by Campbell in 1820 .

Four samples from increasing depths in ash heap C40-50, leaning against stone wall, excavated 1966 and subm. 1967 by R. J. Mason, were selected for dating.

\section{GrN-5307. Kurrichane 1}

Charcoal from 0 to $15 \mathrm{~cm}$ depth.

GrN-5338. Kurrichane 2

Charcoal from 15 to $30 \mathrm{~cm}$ depth.

GrN-5339. Kurrichane 3

Charcoal from 75 to $90 \mathrm{~cm}$ depth.

GrN-5137. Kurrichane 4
A.D. 1812

$138 \pm 30$

$\delta C^{13}=-25.0 \%$

A.D. 1734

$216 \pm 33$

$\delta C^{13}=-24.3 \%$

A.D. 1813

$137 \pm 32$

$\delta C^{13}=-23.9 \%$

A.D. 1747

$203 \pm 44$

$\delta C^{13}=-23.35 \%$

Charcoal from 106 to $122 \mathrm{~cm}$ depth. Natural surface at $137 \mathrm{~cm}$. 


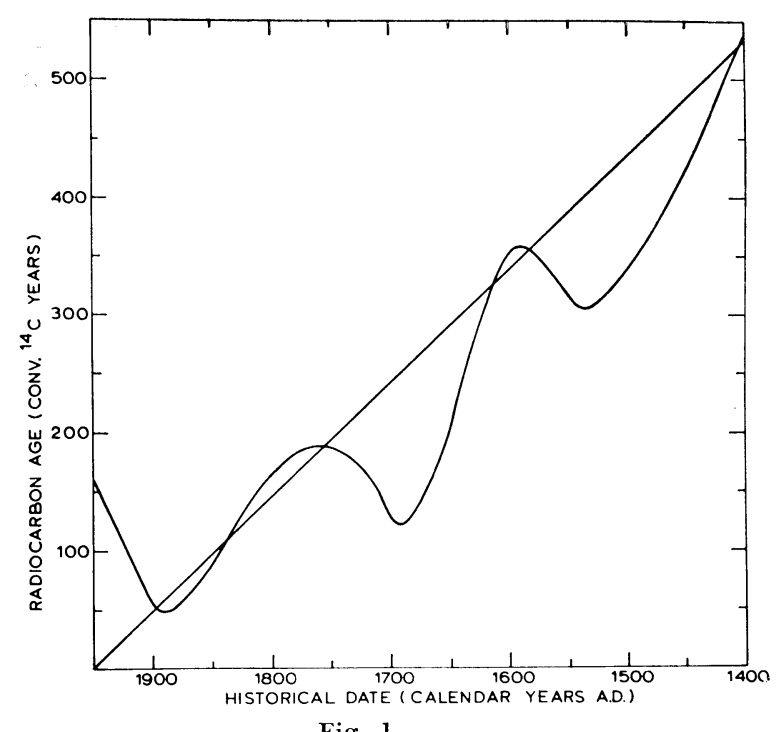

Fig. 1

General Comment: since true age must increase with increasing depth, most probable historic dates for each sample as selected from calibration curve (Fig. 1) are A.D. $1825 \pm 25$, A.D. $1770 \pm 30$, A.D. $1700 \pm 30$, and A.D. $1650 \pm 20$, respectively.

\section{Olifantspoort series, Transvaal}

Extensive stone-walled Iron age settlement on farm Olifantspoort ( $25^{\circ} 47^{\prime} \mathrm{S}$ Lat, $27^{\circ} 15^{\prime} \mathrm{E}$ Long), Rustenburg dist., Transvaal, produced pottery of Buispoort type (Mason, 1962). Trial trench in refuse heap against $2 \mathrm{~m}$ stone wall excavated by Mason and Vogel, 1967, in $15 \mathrm{~cm}$ layers to collect stratigraphic sequence of charcoal samples. Heavily abraded stone flakes found in Iron age context during excavation (Mason, 1969). Subm. by R. J. Mason.

\section{GrN-5304. Olifantspoort 1}

Charcoal from 0 to $15 \mathrm{~cm}$ depth.

\section{GrN-5305. Olifantspoort 2}

Charcoal from 50 to $60 \mathrm{~cm}$ depth.

\section{GrN-5306. Olifantspoort 3}

$105 \pm 35$ A.D. 1845 $\delta C^{13}=-24.3 \%$

$$
180 \pm 30
$$

A.D. 1770

$\delta C^{13}=-24.9 \%$

$$
105 \pm 25
$$

\section{A.D. 1845}

$\delta C^{13}=-24.8 \%$

Charcoal from bottom of ash heap at $90 \mathrm{~cm}$ depth.

General Comment: following same method of successive elimination of possible historic dates as for Vergenoegd series above, most probable 
date for accumulation of deposit is between A.D. $1695 \pm 20$ and A.D. 1845 \pm 30 . Of 11 dates for this culture (see also Vogel and Waterbolk, 1967, Klipriviersberg and Waterval) it appears that stone-walled settlements in this area were occupied from at least A.D. $1640 \pm 20$ to A.D. $1845 \pm$ 30. Latter date in good agreement with historically documented inroad of Moselikatse into Transvaal in 1820's which marked destruction of existing tribal system in area.

III. GEOPHYSICAL SAMPLES

\section{A. Atmospheric carbon dioxide}

\section{Groningen series, Netherlands}

When nuclear weapon testing was resumed in Sept. 1961, atmospheric $\mathrm{CO}_{2}$ samples were coll. on top of $30 \mathrm{~m}$ VandeGraaff tower of the Physics Lab., Univ. of Groningen in W suburb of city $\left(53^{\circ} 54^{\prime} \mathrm{N}\right.$ Lat, $6^{\circ} 33^{\prime} \mathrm{E}$ Long). Collection by exposing $1.5 \mathrm{~L}$ of $0.5 \mathrm{~N} \mathrm{NaOH}$ in $900 \mathrm{~cm}^{2}$ tray for ca. 3 days.

Sample no.

Date

GrN-3091

GrN-3087

GrN-3129

GrN-3143

GrN-3145

GrN-3123

GrN-3144

GrN-3135

GrN-3146

GrN-3607

GrN-3209

GrN-3207

\begin{tabular}{|c|c|}
\hline Date & $\delta \mathrm{C}^{14}(\% 0)$ \\
\hline Oct. 31-Nov. 3, 1961 & $192 \pm 6$ \\
\hline Nov. 6-Nov. 9, 1961 & $138 \pm 6$ \\
\hline Nov. 10-Nov. 13, 1961 & $157 \pm 6$ \\
\hline Nov. $16-$ Nov. 19,1961 & $199 \pm 5$ \\
\hline Nov. 21-Nov. 24, 1961 & $120 \pm 5$ \\
\hline Nov. 28-Dec. 1,1961 & $186 \pm 6$ \\
\hline Dec. 4-Dec. 7, 1961 & $184 \pm 6$ \\
\hline Dec. 15-Dec. 22, 1961 & $135 \pm 6$ \\
\hline Jan. 15-Jan. 18, 1962 & $201 \pm 7$ \\
\hline Feb. 16-Feb. 19,1962 & $219 \pm 7$ \\
\hline Mar. 16-Mar. 19, 1962 & $239 \pm 8$ \\
\hline Apr. 16-Apr. 19,1962 & $260 \pm 6$ \\
\hline
\end{tabular}

Comment: no $\mathrm{C}^{13}$ corrections applied, but by comparison with other stations, corrections are small. Apparently all samples coll. here in winter $1961 / 62$ are contaminated by fossil $\mathrm{CO}_{2}$.

Compare: GrN-3633, Vermunt 5, Dec. 8, 1961, $\delta \mathrm{C}^{14}=216 \pm 7 \%$. Atmospheric $\mathrm{CO}_{2}$ from Vermunt, Schruns (47 $04^{\prime} \mathrm{N}$ Lat, $9^{\circ} 55^{\prime} \mathrm{E}$ Long), Voralberg, Austria, supplied by K. O. Münnich, Univ. of Heidelberg, Heidelberg, Germany. Collection, therefore, shifted to Smilde, see below.

\section{Smilde series, Netherlands}

Atmospheric $\mathrm{CO}_{2}$ coll. on $80 \mathrm{~m}$ level of television tower at Hoogersmilde (52 $54^{\prime} \mathrm{N}$ Lat, $6^{\circ} 24^{\prime} \mathrm{E}$ Long), Prov. of Drente, Netherlands, 15 $\mathrm{km}$ from nearest large town (Assen) and $500 \mathrm{~m}$ from main road. Contamination considered small, since tower is in relatively thinly populated area and wind frequently strong. Coll. under supervision of $\mathrm{H}$. $\mathrm{H}$. Welling, engineer-in-charge. Method as at Groningen (above). Normalized to $\delta \mathrm{C}^{13}=-25 \%$. 


\begin{tabular}{llccr} 
Sample no. & \multicolumn{2}{c}{ Date } & $\delta \mathrm{C}^{13}(\%)$ & $\Delta(\%)$ \\
\hline GrN-3249 & May 5-May 8, 1962 & $(-26) *$ & $291 \pm 8$ \\
GrN-3251 & July 6-July 9, 1962 & $(-26)$ & $423 \pm$ \\
GrN-4015 & Aug. 6-Aug. 9, 1962 & $(-26)$ & $423 \pm 7$ \\
GrN-4019 & Aug. 22-Aug. 25, 1962 & $(-26)$ & $431 \pm 6$ \\
GrN-4020 & Sept. 17-Sept. 20, 1962 & $(-26)$ & $431 \pm 8$ \\
GrN-4021 & Oct. 1-Oct. 4, 1962 & $(-26)$ & $355 \pm$ & \pm \\
GrN-4022 & Oct. 15-Oct. 18, 1962 & $(-26)$ & $395 \pm$ \\
GrN-4046 & Nov. 16-Nov. 19, 1962 & -29 & $383 \pm 9$ \\
GrN-4047 & Dec. 14-Dec. 17, 1962 & -24 & $389 \pm 13$ \\
GrN-4079 & Jan. 15-Jan. 18, 1963 & -26 & $392 \pm 10$ \\
GrN-4081 & Feb. 15-Feb. 18, 1963 & -31 & $409 \pm$ \\
GrN-4082 & Mar. 12-Mar. 15, 1963 & $(-26)$ & $465 \pm$ \\
GrN-4106 & Mar. 27-Mar. 31, 1963 & -27 & $488 \pm 10$ \\
GrN-4107 & Apr. 16-Apr. 19, 1963 & -25 & $571 \pm 10$ \\
GrN-4109 & May 21-May 24, 1963 & -25 & $646 \pm 10$ \\
GrN-4128 & July 17-July 21, 1963 & -25 & $897 \pm 9$ \\
GrN-4129 & Aug. 1-Aug. 5, 1963 & -25 & $927 \pm 10$ \\
GrN-4130 & Aug. 12-Aug. 15, 1963 & -24 & $946 \pm$ \\
GrN-4131 & Aug. 19-Aug. 22, 1963 & -24 & $1004 \pm$ \\
GrN-4189 & Oct. 4-Oct. 7, 1963 & -24 & $952 \pm 11$ \\
GrN-4190 & Oct. 18-Oct. 23, 1963 & -25 & $881 \pm 7$ \\
GrN-4192 & Nov. 8-Nov. 11, 1963 & -27 & $816 \pm 11$ \\
\hline
\end{tabular}

Comment: data cover main rise in $\mathrm{C}^{14}$ to maximum in Aug. 1963 and correspond closely to other pub. values for $\mathrm{N}$ hemisphere.

\section{Pretoria series, South Africa}

Atmospheric $\mathrm{CO}_{2}$ coll. at Radioactivity Div., Nat. Physics Research Lab. $\left(25^{\circ} 50^{\prime} \mathrm{S}\right.$ Lat, $28^{\circ} 20^{\prime} \mathrm{E}$ Long), some $15 \mathrm{~km} \mathrm{E}$ of Pretoria, South Africa, under supervision of W. R. McMurray and C. Verwey. For shipment, samples were precipitated as $\mathrm{BaCO}_{3}$. Site should be reasonably free from contamination by fossil $\mathrm{CO}_{2}$ although smog from city occasionally can reach lab.

\begin{tabular}{llccc} 
Sample no. & \multicolumn{1}{c}{ Date } & $\delta \mathrm{C}^{13}(\%)$ & $\Delta(\%)$ \\
\hline GrN-4138 & Oct. 16-Oct. 19, 1962 & -24.3 & $281 \pm 9$ \\
GrN-4281 & Oct. 29-Nov. 1, 1962 & $(-23) *$ & $272 \pm 6$ \\
GrN-4137 & Nov. 12-Nov. 15, 1962 & -22.6 & $276 \pm 8$ \\
GrN-4136 & Jan. 7-Jan. 10, 1963 & -22.0 & $282 \pm 8$ \\
GrN-4142 & Apr. 1-Apr. 4, 1963 & -25.1 & $308 \pm 8$ \\
GrN-4135 & Apr. 15-Apr. 18, 1963 & -23.8 & $278 \pm 8$ \\
GrN-4134 & May 13-May 16, 1963 & -21.1 & $308 \pm 8$ \\
GrN-4283 & June 1-June 10, 1963 & -22.4 & $337 \pm 6$ \\
\hline
\end{tabular}

* $\mathrm{C}^{13}$ values in brackets are estimated. 


\begin{tabular}{llccc} 
Sample no. & \multicolumn{2}{c}{ Date } & $\delta \mathrm{C}^{13}(\%$ $)$ & $\Delta(\%$ ) \\
\hline GrN-4284 & July 22-July 25, 1963 & -23.9 & $325 \pm 7$ \\
GrN-4285 & Oct. 14-Oct. 17, 1963 & -22.4 & $444 \pm 7$ \\
GrN-4286 & Mar. 2-Mar. 5, 1964 & -22.2 & $537 \pm 6$ \\
GrN-4282 & Apr. 14-Apr. 17, 1964 & -22.3 & $551 \pm 5$ \\
GrN-4683 & May 5-May 8, 1964 & -22.1 & $521 \pm 4$ \\
GrN-4684 & June 2-June 15, 1964 & -21.8 & $546 \pm 3$ \\
GrN-4352 & July 20-July 23, 1964 & -22.7 & $549 \pm 7$ \\
GrN-4353 & Aug. 3-Aug. 6, 1964 & -20.9 & $542 \pm 6$ \\
GrN-4354 & Aug. 25-Aug. 28, 1964 & -23.3 & $594 \pm 4$ \\
GrN-4355 & Sept. 8-Sept. 14, 1964 & -22.3 & $600 \pm 4$ \\
GrN-4382 & Oct. 6-Oct. 9, 1964 & -22.5 & $624 \pm 6$ \\
GrN-4472 & Oct. 26-Oct. 29, 1964 & -23.1 & $655 \pm 3$ \\
GrN-4578 & Nov. 23-Nov. 26, 1964 & -24.2 & $626 \pm 3$ \\
GrN-4579 & Feb. 22-Feb. 25, 1965 & -23.1 & $645 \pm 3$ \\
GrN-4687 & Mar. 18-Mar. 21, 1965 & -22.6 & $602 \pm 4$
\end{tabular}

General Comment: series covers main increase of radiocarbon in S Hemisphere. By Oct. 1964 level had become equal to that in $\mathrm{N}$ Hemisphere. Steeper increase during $\mathrm{S}$ spring suggests some N-S transport via stratosphere.

\section{B. Surface ocean water}

\section{Atlantic Ocean series}

Surface ocean water samples coll. during voyage 38 of S.A. Vaal from Southampton, U.K., to Cape Town, South Africa, 23 June-5 July, 1967, by J. C. Vogel with the generous help of Captain N. M. Lloyd, officers and crew. Inorganic carbon extracted from $60 \mathrm{~L}$ samples on board by method described by Vogel (1967).

\begin{tabular}{|c|c|c|c|c|}
\hline Sample no. & Date & Lat, Long & $\delta \mathrm{C}^{13}(\% 0)$ & $\begin{array}{c}\mathrm{C}^{14} \\
(\% \text { modern })\end{array}$ \\
\hline GrN-5244 & June 24,1967 & $44^{\circ} 50^{\prime} \mathrm{N}$ & +0.65 & $112.9 \pm .9$ \\
\hline GrN-5301 & June 25, 1967 & $36^{\circ} 00^{\prime} \mathrm{N}, \quad 12^{\circ} 20^{\prime} \mathrm{W}$ & +1.43 & $115.1 \pm .6$ \\
\hline GrN-5258 & June 26, 1967 & $28^{\circ} 40^{\prime} \mathrm{N}, 15^{\circ} 10^{\prime} \mathrm{W}$ & +1.39 & $116.0 \pm .8$ \\
\hline GrN-5280 & June 27, 1967 & $19^{\circ} 40^{\prime} \mathrm{N}, \quad 18^{\circ} 00^{\prime} \mathrm{W}$ & +1.11 & $105.2 \pm .7$ \\
\hline GrN-5331 & June 28, 1967 & $12^{\circ} 19^{\prime} \mathrm{N}, \quad 17^{\circ} 30^{\prime} \mathrm{W}$ & +0.79 & $107.3 \pm 1.1$ \\
\hline GrN-5259 & June 29, 1967 & $2^{\circ} 52^{\prime} \mathrm{N}, 1^{\circ} 15^{\prime} \mathrm{W}$ & +1.21 & $112.5 \pm .7$ \\
\hline GrN-5302 & June 30,1967 & $2^{\circ} 00^{\prime} \mathrm{S}, \quad 7^{\circ} 10^{\prime} \mathrm{W}$ & +1.07 & $107.2 \pm .6$ \\
\hline GrN-5303 & July 1,1967 & $8^{\circ} 45^{\prime} \mathrm{S}$ & +1.93 & $111.4 \pm .5$ \\
\hline GrN-5260 & 2,1967 & $15^{\circ} 45^{\prime} \mathrm{S}$ & +1.79 & $108.3 \pm .6$ \\
\hline GrN-5330 & 3,1967 & $22^{\circ} 10^{\prime} \mathrm{S}, \quad 9^{\circ} 20^{\prime} \mathrm{E}$ & +0.67 & $108.0 \pm .7$ \\
\hline GrN-5345 & 4, 1967 & $27^{\circ} 40^{\prime} \mathrm{S}, \quad 14^{\circ} 30^{\prime} \mathrm{E}$ & +0.84 & $104.9 \pm .6$ \\
\hline GrN-5245 & 4, 1967 & $31^{\circ} 00^{\prime} \mathrm{S}, \quad 16^{\circ} 45^{\prime} \mathrm{E}$ & +0.29 & $108.0 \pm .7$ \\
\hline
\end{tabular}


General Comment: some samples (GrN-5280, 5331, 5345) show low values due to upwelling of deep water near W coast of Africa. Rest show smooth variation with lat. except for unexplained high value of GrN-5303. Remarkable fact is that North Atlantic samples correspond exactly with data of Münnich and Roether (1967) for 1965, suggesting that no further increase of atom bomb $\mathrm{C}^{14}$ in surface water took place in those years.

\section{REFERENCES}

Brain, C. K. and Cooke, C. K., 1967, A preliminary account of the Redcliff stone age cave site in Rhodesia: S. Afr. Archaeol. Bull., v. 21, p. 171-182.

Coetzee, J. A., 1964, Evidence for a considerable depression of the vegetation belts during the upper Pleistocene on the East African mountains: Nature, v. 204, p. 564-566. of Africa, v. 3, p. 1-146.

Coetzee, J. A. and Vogel, J. C., 1967, Evidence for the Paudorf Interstadial in Africa: Palaeoecology of Africa, v. 2, p. 100-101.

Dart, R. A. and Beaumont, P., 1969a, Evidence of iron ore mining in southern Africa in the Middle Stone age: Current Anthropol., v. 10, p. 127-128. $1969 b$, Iron age radiocarbon dates from Western Swaziland: S. Afr.
Archaeol. Bull., v. 24, p. 71 .

Dreyer, T. F., 1938, The archaeology of the Florisbad deposits: Argeol. Navorsing Nas. Mus. Bloemfontein, v. 1, p. 65-77.

van der Hammen, T., Maarleveld, G. C., Vogel, J. C., and Zagwijn, W. H., 1967, Stratigraphy, climatic succession and radiocarbon dating of the last glacial in the Netherlands: Geol. en Mijnbouw, v. 46, p. 79-95.

Lerman, J. C., Mook, W. G., and Vogel, J. C., $1970,{ }^{14} \mathrm{C}$ in tree-rings from different localities: XII Nobel symp. Proc., Stockholm, in press.

Louw, A. W., Brain, C. K., Vogel, J. C., Mason, R. J., and Eloff, J. F., 1969, Bushman Rock Shelter: S. Afr. Archaeol. Bull., v. 24, p. 39-60.

Louw, J. T., 1960, Prehistory of the Matjes River rock shelter: Nat. Mus., Bloemfontein, mem. no .1.

Mahé, J., 1965, Les subfossiles Malgache: Imprimerie Natle., Tananarive.

Malan, B. D., 1952, The final phase of the Middle Stone age in South Africa: 1st Pan-Afr. cong. on Prehistory Proc., Nairobi, 1947, Oxford, p. 188-194.

Mason, R. J., Prehistory of the Transvaal: Johannesburg, Witwatersrand Univ. Press. 1968, Transvaal and Natal Iron age settlement revealed by aerial photography and excavation: Afr. Studies, v. 27, p. 1-14.

raphy and excavation: Afr. Studies, v. 27, p. 1-14. Kaditshwene, Zeerust district: S. Afr. Jour. Sci., v. 65, p. 41-44.

Meiring, A. J. D., 1956, The macrolithic culture of Florisbad: Res. Nat. Mus. Bloemfontein, v. 1, p. 205-237.

Münnich, K. O. and Roether, W., 1967, Transfer of bomb ${ }^{14} \mathrm{C}$ and tritium from the atmosphere to the ocean. Internal mixing of the ocean on the basis of tritium and ${ }^{14} \mathrm{C}$ profiles: Radioactive dating and methods of low-level counting, I.A.E.A., Vienna, p. 93-104.

Robins, P. A. and Swart, E. R., 1964, Southern Rhodesian radiocarbon measurements I: Radiocarbon, v. 6, p. 31-36.

Schalke, H. J. W. G. and van Zinderen Bakker, E. M., 1967, A preliminary report on palynological research on Marion Island (sub-Antarctic): S. Afr. Jour. Sci., v. 63, p. 254-259.

Seddon, J. D., 1966, Kurrichane: a late Iron age site in Western Transvaal: Afr. Studies, v. 25 , p. $227-231$.

Simpson, E. S. W. and Haydorn, A. E. F., 1965, Vema Seamount: Nature, v. 207, p. 249-251.

Straka, H., 1960, Über Moore und Torf auf Madagaskar und den Maskarenen: Erdkunde, v. 14, p. $81-98$.

Vogel, J. C., 1967, Investigation of groundwater flow with radiocarbon: Isotopes in hydrology, I.A.E.A., Vienna, p. 355-369.

Vogel, J. G. and Waterbolk, H. T., 1967, Groningen radiocarbon dates VII: Radiocarbon, v. 9, p. 107-155. 
Vogel, J. C. and Zagwijn, W. H., 1967, Groningen radiocarbon dates VI: Radiocarbon, v. 9, p. 63-106.

de Vries, H., 1958, Variation in concentration of radiocarbon with time and location on Earth: Koninkl. Nederlandse Akad. Wetensch. Proc., ser. B, v. 61, no. 2, p. 1-9.

de Waard, H. and Straka, H., 1961, C ${ }^{14}$-Datierung zweier Torfproben aus Madagaskar: Naturwissenschaften, v. 48 , p. 45

Welte, D. H. and Eberhardt, G., 1968, Distribution of long chain n-paraffins and n-fatty acids in sediments from Persian Gulf: Geochim. et Cosmochim. Acta, v. 32, p. $465-466$.

van Zinderen Bakker, E. M., 1955, A pollen analytical investigation of the Florisbad deposits (South Africa): IIIrd Pan-Afr. cong. on Prehistory Proc., p. 56-67. 1962, A Late-Glacial and Post-Glacial climatic correlation between East Africa and Europe: Nature, v. 194, p. 201-203.

1964, A pollen diagram from Equatorial Africa, Cherangani, Kenya: Geol. en Mijnbouw, v. 43, p. 123-128. 